\title{
Application of Micro Lesson on Public English Teaching in Higher Vocational Colleges
}

\author{
Yang Juan \\ Changjiang Institute of Technology, Wuhan, 430212, China
}

Keywords: micro lesson; higher vocational Public English; application

\begin{abstract}
With the rapid development of Chinese economy, higher vocational education has ushered in a very good opportunity for development. However, in higher vocational education, public English education has always been a weakness. At this stage, there are still some problems that need to be solved in our higher vocational English education. The rise of micro teaching mode provides a very good opportunity for solving these problems. This paper, starting with the definition of micro lesson, analyzes the problems in the present stage of Public English education in higher vocational education in China, and points out the role of micro class on improving the effect of Public English teaching, and hopes to provide some help for the Public English in higher vocational education.
\end{abstract}

The teaching mode of "micro lesson" appears very late in the field of education. Compared with the traditional teaching mode, the micro lesson teaching mode is undoubtedly more flexible. Micro courses also provide a new way of thinking for educational reform in the current educational reform. In higher vocational colleges, Public English courses have quite a number of knowledge points and practical teaching aims, and these features have some interoperability with the characteristics of the micro lesson. It can be said that the effective use of "micro lesson" teaching mode in higher vocational Public English teaching can not only greatly improve the teaching effect of Public English, but also is very beneficial to the development of the Public English in higher vocational colleges and universities.

\section{The Definition of Micro Lesson}

Taking video as the main carrier, the so-called micro lesson is a teaching mode that teachers carry out a short time and relatively independent knowledge around a knowledge point. Under normal circumstances, the length of the micro teaching video will not exceed ten minutes. For the students, it is necessary to consolidate the knowledge points by studying materials carefully and increasing the after-school exercises through the micro class video after learning the knowledge points. Compared with the traditional teaching mode, the content of the micro class teaching is short and delicate, and the teaching goal is clearer. It can be focused on the students' common knowledge point which is not easy to understand. Therefore, it can help to improve the teaching effect of the Higher Vocational Public English.

\section{The Application of Micro Lesson in Higher Vocational Public English Teaching.}

Micro class is "micro", because the micro class teaching video is very short, it can display the knowledge to students in no time. However, at the present stage, many teachers only pay attention to the shortness of the microlesson video in the design of the teaching content of the microcourses, but do not inject the content of the system in the short video. In this case, we will find that the content of many micro class teaching videos at the present stage is relatively rough, and cannot be fully taught and displayed for the knowledge points. In the form of expression, at present, most teachers in China use PPT when making micro Lesson Videos. Objectively, PPT is the most commonly teaching form whose advantages are beyond doubt. However, at present, most teachers in Higher Vocational Public English major only use PPT when making micro class video, but they 
do not know or want to use other teaching forms, which leads to the single and dull form of micro class video at the present stage, which cannot arouse the students' interest in learning.

The production process of micro lesson is a very systematic and complicated project. However, at this stage, most of China's Higher Vocational Public English teachers have not been guided by professional instruction on making micro class video, and often go into various misunderstandings in the process of production. In addition, some teachers do not realize the real role of the micro class, so they do not pay much attention to the process of making micro courses, which makes the micro video fail to play a real role. Finally, in the process of using micro class to teach, many teachers ignore the main position of students in education. The micro class video cannot meet the students' real learning needs and cannot effectively promote the improvement of students' learning effect. In this case, the role of micro class teaching cannot be really played, and the failure to play a full role in the micro class teaching will lead to the negligence to teachers and a vicious circle.

At the present stage, many higher vocational public English teachers in our country do not really understand the connotation and function of the micro class teaching, so it has great randomness when designing the content of the microcourse video. In particular, some of the micro class video produced by some teachers often contain a number of scattered knowledge points, rather than a single understanding of a single point of knowledge, which leads to the lack of systematic content of the micro lesson video. Under such circumstances, many students simply cannot solve the difficult problems encountered in their English learning by watching micro Lesson Videos. In addition, taking this lack of systematic micro video as the teaching material is impossible to connect all the knowledge points in series, which is not conducive to the formation of a systematic English knowledge system. The effect of the teaching is bound to be discounted.

\section{Problems of the Teaching of Public English in Higher Vocational Education in China}

At present, most of the higher vocational colleges in China, the mode of Public English teaching is still the teachers' explanation - students listen to lectures - after class exercises. Through the investigation, it is found that most of the students are not interested in learning in the face of this old teaching method, which is also an important reason for the poor performance of Public English in many higher vocational colleges. This kind of teaching model has existed for several decades in our country, and its great influence is deeply rooted. Not only the English Teaching of higher vocational colleges is affected by it, but in many colleges and universities, the traditional teaching mode is still in the way. Objectively speaking, because of the strong teaching effect, the traditional teaching method can exist for a long time, and still has strong vitality until now.. However, it is difficult for students to produce enough learning interest for a long time to face the same teaching content, so their learning effect cannot be guaranteed. For the teaching work of a certain subject, the too single teaching mode is a great obstacle to the continuous progress and development of the subject, which is not conducive to the sustainable development of the subject. For Higher Vocational Public English teaching, it is necessary to innovate the traditional teaching mode if it wants to develop its own teaching mode and improve the effect of teaching. However, the new micro teaching model can be used as an attempt to innovate the teaching mode of Public English in higher vocational colleges.

As mentioned before, at present, the teaching of Public English subjects in Higher Vocational Colleges in China still uses traditional teaching methods which can date back to decades ago. In practice, this teaching method is rather old. In China's higher vocational colleges, the students who choose to learn public English have more or less English foundation, and they have received different degrees of English education in both primary and secondary schools. When they step into higher vocational colleges and begin the study of Public English, the students will lose interest in the learning of Public English in a short time, even rejecting to the English class, when they found the teaching mode is the same as before. Under such circumstances, the effect of learning public English and the quality of learning cannot be guaranteed. At the present stage, the students of Higher Vocational Colleges in our country are mainly post 90s and a few are even post 00s. These students are more active in thinking, so the weariness of learning from the outdated and backward 
education methods is more serious. In some vocational colleges, there is even a lack of interest in students' English learning in whole major. Under such circumstances, teachers' teaching tasks cannot be completed at all, and students will face setbacks in the workplace after graduation because of their inadequate English proficiency. In the face of this problem, teachers must innovate the traditional teaching methods, and have to use various teaching methods flexibly, mobilize the atmosphere of the classroom and attract the students' interest to the public English class.

Compared with other institutions, higher vocational colleges have high requirements for the practicality of their own disciplines. The reason for this is not only to ensure that students have enough knowledge and skills after graduation, but also to ensure that more qualified technicians are invested in social production and economic construction. In comparison, the teaching of Public English is more biased towards the theory, but it has a high requirement for the practicality of the teaching content, so that the graduates of higher vocational colleges can have enough English literacy and professional level. However, what must be seen is that the present stage of Public English Teaching in Higher Vocational Colleges in our country is still biased towards theory, and there is still a certain distance between the practical aspect and the training goal of the higher vocational colleges. Although this situation has been improved to a certain extent, the pace of improvement is still very slow. Under the current mainstream English education and examination system, English education is still difficult to get rid of "paper talk". Many students who have passed primary school to college English education still have great shortcomings in oral expression and communication. Judging from the pace of educational reform at this stage, we still have a long way to go to really solve this problem. In higher vocational colleges, because of its higher requirement for the practicability in Public English, innovative teaching mode has become an inevitable choice.

\section{Measures to Strengthen Micro Lesson in Public English Teaching in Higher Vocational Colleges and Universities}

For the current higher vocational colleges, it is an important way to innovate the existing teaching mode. In the public English teaching activities in higher vocational colleges, this new teaching mode will have a far-reaching impact. In essence, the micro class teaching mode is to use flexible methods to re-integrate educational resources. In the process of Public English Teaching in the use of microcourses, teachers can record the knowledge points and knowledge structures in the textbook into micro class video and store them properly. After that, once teachers or students have needs, they can quickly and accurately extract corresponding micro class videos for teaching or learning. Under this new teaching mode, the autonomy of students' learning will be released to a large extent, thus changing the traditional teaching mode of Public English in higher vocational colleges. With the rapid development of multimedia and information technology, the cost of introducing micro courses into teaching activities has been accepted by the vast major higher vocational colleges. Under such circumstances, teachers should take the initiative to try out micro teaching. In the micro class teaching mode, the students will realize the different learning atmosphere and way of learning, and then improve the effect of learning. In this process, in addition to the need to design excellent micro lesson video works, teachers should also teach students the methods of learning by using micro lessons, and make effective study on them

In the public English Teaching of higher vocational colleges, the role played by micro courses is very important. In the micro class teaching mode, in addition to reprocessing the knowledge points and knowledge frames in the teaching materials, the teachers can also innovate the methods of micro lesson teaching in the process of using micro class video to carry out teaching activities. In addition, in the use of micro class teaching, teachers should change the past one-way teaching mode, use micro lessons to increase the interaction with students, and use students' evaluation and feedback to further improve their teaching methods. Under such a mode, teachers' stress on teaching will be reduced, and the enthusiasm and initiative of students to participate in classroom teaching can be greatly improved. For the students of higher vocational colleges, the micro class video can be stored for a long time, and it is short, so when the students are learning in the teaching mode of the micro class, they can make the study plan more independently and arrange their time of study 
flexibly. Under such circumstances, they can make use of the micro lesson video to focus on their difficulties in learning. Compared with the old "spoon feeding" education, this new teaching mode can undoubtedly stimulate students' enthusiasm for learning. Furthermore, as the micro class video is generally relatively short, the longest is not more than ten minutes, so it is not easy for students to feel irritable and impatient in the process of learning, which is very important to improve the efficiency and quality of learning.

At present, some higher vocational colleges in China's coastal developed areas have begun to apply micro teaching mode in teaching activities. In view of the important role of micro teaching mode in guaranteeing the quality of teaching, some professional English education institutions also have begun to use micro teaching. However, for the public English teachers in higher vocational colleges, it is not enough to imitate others' advanced experience simply to really grasp the essence of the teaching model of the micro class. In order to make micro teaching really play a role, teachers must expand the existing teaching content and enhance the practicality of teaching content. For example, when making a micro - lesson video, the relevant scene simulation, or the related film and television resources, should be properly added to the video based on the different points of knowledge to be taught. Compared with the traditional teaching mode, the teaching resources contained in the micro course are undoubtedly more colorful. For the public English teachers in higher vocational colleges, they have more space to play the micro class video. They can add more practical content to the micro class teaching video, so as to arouse the students' interest and enhance the practicality of the teaching content.

\section{Summary}

For higher vocational colleges, it is undoubtedly a correct choice to introduce micro lessons into public English teaching. For teachers, the use of micro class teaching can not only greatly alleviate the pressure of teaching, but also can greatly improve the practicality of the content of the teaching of Public English, and then improve the teaching effect and quality. For students, the use of micro courses in public English learning can greatly enhance their learning enthusiasm and initiative. The teacher wants to ensure that the teaching of the micro class plays an increasingly important part, they should not only innovate the traditional teaching mode, arouse the enthusiasm and initiative of the students' learning, but also to expand the existing teaching content, and increase the practicality of the content of the teaching of Public English, and then ensure the effect and quality of the teaching.

\section{References}

[1] Sun J. Application of Microlecture in Public English Teaching of Higher Vocational College [J]. Shipbuilding Vocational Education, 2017.

[2] Sun Z Y. Construction and Application of Public English Teaching in High Vocational Colleges in MOOCs Context [J]. Journal of Changsha Aeronautical Vocational \& Technical College, 2017.

[3] Li S, Literature D O, Amp A. Study on the Application of We Chat Public Platform- based Flipped Classroom in Higher Vocational English Teaching [J]. Journal of Baotou Vocational \& Technical College, 2016.

[4] Chen L Y. Application of micro teaching in the teaching of applied writing in higher vocational college [J]. Journal of Nanchang College of Education, 2016.

[5] Hai-Li L I. The Application of "Micro-Course" in English Teaching in Higher Vocational Colleges [J]. Journal of Hubei Correspondence University, 2017.

[6] Wei C, Humanities D O, Academy S P. The Application of Flipped Classroom in English Teaching in Higher Vocational Colleges [J]. Journal of Hubei Correspondence University, 2017. 